University of Nebraska - Lincoln

DigitalCommons@University of Nebraska - Lincoln

May 2002

\title{
Relationship of Sorghum kernel size to physiochemical, milling, pasting, and cooking properties
}

\author{
W. J. Lee \\ Kangnung National University, Kangnung, 210-702, Republic of South Korea \\ Jeffrey F. Pedersen \\ University of Nebraska-Lincoln, jpedersen1@unl.edu \\ D. R. Shelton \\ Wheat Marketing Center, Inc.
}

Follow this and additional works at: https://digitalcommons.unl.edu/usdaarsfacpub

Part of the Agricultural Science Commons

Lee, W. J.; Pedersen, Jeffrey F.; and Shelton, D. R., "Relationship of Sorghum kernel size to physiochemical, milling, pasting, and cooking properties" (2002). Publications from USDA-ARS / UNL Faculty. 188. https://digitalcommons.unl.edu/usdaarsfacpub/188

This Article is brought to you for free and open access by the U.S. Department of Agriculture: Agricultural Research Service, Lincoln, Nebraska at DigitalCommons@University of Nebraska - Lincoln. It has been accepted for inclusion in Publications from USDA-ARS / UNL Faculty by an authorized administrator of DigitalCommons@University of Nebraska - Lincoln. 


\title{
Relationship of Sorghum kernel size to physiochemical, milling, pasting, and cooking properties
}

\author{
W.J. Lee ${ }^{\mathrm{a}}$, J.F. Pedersen ${ }^{\mathrm{b}, *}$, D.R. Shelton ${ }^{\mathrm{c}}$ \\ ${ }^{a}$ Department of Food Science, Kangnung National University, Kangnung, 210-702, Republic of South Korea \\ ${ }^{\mathrm{b}}$ USDA-ARS Wheat, Sorghum and Forage Research, 344 Keim, University of Nebraska, Lincoln, NE 68583-0937, USA \\ ${ }^{\mathrm{c}}$ Wheat Marketing Center, Inc., 1200 N.W. Naito Parkway, Suite 230, Portland, OR 97209-2800, USA
}

Received 24 May 2001; accepted 23 October 2001

\begin{abstract}
Effects of kernel size on grain sorghum [Sorghum bicolor (L.) Moench] quality were studied in an experiment designed to separate effects of kernel size from seedlot. The study utilized three sieve fractions of varying kernel diameter $(>3.35,>2.80$ and $>2.36 \mathrm{~mm})$ from six seedlots. Chemical composition, physical characteristics, milling characteristics, pasting properties, and cooking qualities were determined for each kernel size fraction. Large kernels lost less relative mass during 1 min of decortication, were higher in protein concentration, and lower in ash. Milling yields were higher from large kernels, and flour from large kernels had higher water absorbance, brighter white color, and larger particle size. Kernel size effects on Rapid Visco Analyzer (RVA) properties were not consistent. These results suggest that within the sorghum seedlots studied, an increase in kernel size is associated with an increase in sorghum quality as defined by the parameters measured in this study. (C) 2002 Elsevier Science Ltd. All rights reserved.
\end{abstract}

Keywords: Sorghum, size; Quality; Hardness; Protein; Milling; Pasting; Cooking

\section{Introduction}

Grain sorghum [Sorghum bicolor (L.) Moench] is the third leading cereal crop in the United States (Sosland, 1998) and fifth leading cereal crop throughout the world (Suhendro, McDonough, Rooney, Waniska, \& Yetneberk, 1998). In the early 1980s an estimated $39 \%$ of global sorghum production was used as food and $54 \%$ for feed. The proportion of sorghum utilized as food has gradually increased as a result of a greater food use in Africa and the substitution of other grains (mainly maize) for sorghum as feed elsewhere. By 1992$1994,42 \%$ of total sorghum utilization was for food and $48 \%$ for animal feed (ICRISAT, 1999).

Large sorghum kernels with corneous endosperm are usually preferred for human consumption (FAO, 1995). A typical sorghum panicle contains between 800 and 3000 kernels. The weights of the kernels increase by over $10 \%$ within a panicle (Heiniger, Vanderlip, \&

* Corresponding author. Tel.: + 1-402-472-1754; fax: + 1-402-4724020.

E-mail address: jfp@unlserve.unl.edu (J.F. Pedersen).
Kofoid, 1993). Variation in kernel size occurs not only between cultivars but within a cultivar obtained from a different location or season (Wills \& Ali, 1983). Relatively little is known about the effect of sorghum kernel size on food quality independent of genotype and environmental effects.

Wills and Ali (1983) reported the effect of kernel size on the decorticating characteristics of 28 Australian sorghum cultivars and suggested cultivars with kernels of non-uniform size should be separated into different sizes and each size grade dehulled for different times for optimal yields during dehulling. Ungraded and sized grain $(<4.00 \mathrm{~mm} ;<3.35$ and $<2.80 \mathrm{~mm}$ diameter, respectively) of 28 sorghum cultivars was dehulled in a pearler (Kett Husk Pearler) for $60 \mathrm{~s}$. The decorticating recovery was higher for kernels $<2.80 \mathrm{~mm}$ than for kernels $<3.35 \mathrm{~mm}$, and kernels $<4.00 \mathrm{~mm}$ gave the lowest recovery.

Textural quality of cooked sorghum grain determines acceptability to consumers (Cagampang, Griffith, \& Kirleis, 1982). For example, sorghum porridges that are too soft and sticky adhere to the teeth and palate during consumption. Grain sorghum cultivars that consistently 
produce relatively firm and nonsticky porridges are preferred by consumers. In sorghum, grain hardness is the most important and consistent characteristic that affects porridges (Rooney, Kirleis, \& Murty, 1986). Aboubacar and Hamaker (1999) reported that hard sorghum grain produced flours containing a high proportion of coarse particles with low ash and high damaged starch content and yielded a higher proportion of desirable sorghum couscous granules.

The objective of this study was to describe the effect of sorghum grain size on physiochemical properties, milling characteristics, pasting properties, and food qualities.

\section{Materials and methods}

\subsection{Description of seedlots and sample preparation}

Six seedlots were selected based on the local availability of adequately large quantities of untreated sorghum grain to recover graded samples for laboratory analyses. All seedlots were produced at the University of Nebraska Field Laboratory, Ithaca, NE. Seedlots 1, 2, 3 were the commercial hybrids Asgro425, $\mathrm{NC}+7 \mathrm{R} 37 \mathrm{E}$, and $\mathrm{NC}+6 \mathrm{R} 55 \mathrm{E}$, respectively, and were grown in 1997. Seedlot 4, BT $\times 623$ was grown in 1994. Seedlot 5 was a $\mathrm{F}_{7}$ selection from the cross A35 $\times$ PI431592, grown in 1998. Seedlot 6 was a $\mathrm{S}_{8}$ selection from a low HCN-p RP2B population grown in 1997. Seedlots were characterized for moisture (AACC method 44-15A, 1995), color, and kernel size index value as described by Rooney and Sullins (1970):

Kernel Size Index was determined by screening 200 g samples of clean grain through a series of Tyler screens. Kernel size index was the sum of the overs of each Tyler sieve multiplied by a constant and divided by 2 .

$$
\begin{aligned}
\text { Kernel size index }= & {[(\# 5)(0.5)+(>\# 6)(0.6)} \\
& +(>\# 7)(0.7)+(>\# 8)(0.8)] / 2
\end{aligned}
$$

Kernel moisture, color, and kernel size index values for the individual seedlots were: Seedlot 1: $12.5 \%$, red, 65.0; seedlot 2: $12.9 \%$, red, 66.1 ; seedlot $3: 12.6 \%$, red, 66.8; seedlot 4: $13.0 \%$, white, 67.9 ; seedlot 5: $12.8 \%$, white, 68.6; and seedlot 6: 13.1\%, white, 70.3. Higher kernel size index numbers indicate smaller average kernel size. All samples were stored at $\approx 5^{\circ} \mathrm{C}$ until used and hand-cleaned to remove pieces and debris. Seedlots were graded into large, medium, and small kernel size classes by sieving with a Tyler Rotap shaker on US 6, 7, and 8 Tyler screens with meshs of $3.35,2.80$ and $2.36 \mathrm{~mm}$, respectively.

\subsection{Physiochemical properties of ground whole-grain samples}

The graded samples were ground in a Udy Cyclone sample mill (Udy Corporation, Fort Collins, CO) using a $0.5-\mathrm{mm}$ screen before analysis. Ash content was determined by the muffle furnace method (AACC method 08-01, 1995). Protein concentration was determined with a combustion nitrogen analyzer (Model CN2, 000, Leco Corp., St. Joseph, MI), using 6.25 as the factor to convert nitrogen to protein (AACC method 46-18, 1995). Total starch was estimated by AACC Approved Method 76-13 (1995) using the Megazyme Kit (Megazyme, Ireland).

Ground grain samples were placed in a GranularMaterial Attachment CR-A50 and their colors were measured with a Minolta Chroma Meter 300 (Minolta Camera Co., Ltd., Osaka, Japan) using the CIE 1976 Chromameter $L^{*}, a^{*}, b^{*}$ color scale equipped with a standard C illuminant. $L^{*}$ value expressed the whiteness of the sample with 100 as perfect white and 0 as black. A higher $L^{*}$ value indicate a brighter or whiter sample. Values of $a^{*}$ and $b^{*}$ indicated the red-green and yellowblue chromaticity, respectively. Positive $a^{*}$ and $b^{*}$ values expressed the increased redness and yellowness, respectively. A value of 0 in $a^{*}$ and $b^{*}$ indicated gray.

Graded samples from each seedlot were dehulled in a Tangential Abrasive Dehulling Device (TADD, model 4E-220, Venables Machine Works Ltd., Saskatoon, Saskatchewan) with eight cups and a 128-grist abrasive surface as described by Oomah, Reichert, and Youngs (1981). Grain hardness (grams of matter removed per $100 \mathrm{~g}$ of whole grain) was measured by 1-min decortication of $20 \mathrm{~g}$ samples. The mass of dehulled grain was calculated as a percentage of the original weight of grain.

\subsection{Dry milling and flour characteristics}

Grain sorghum pericarp was eliminated by a separate decortication process before crushing endosperm to flour (Perten, 1976). The kernels were decorticated to remove about $30 \%$ of their weight by using the Tangential Abrasive Dehulling Device. Decorticated samples were milled on a Brabender Quadrumat Junior Mill (C.W. Brabender Instruments, Inc., South Hackensack, NJ). A short tempering time (20 min), and an intermediate moisture $(14 \%)$ were used after hull removal and prior to milling (Farias, 1986). Dry milling yield was expressed as percent of original sample weight.

Flour color was measured with a Minolta Chroma Meter 300 as described for color measurement of ground grain (earlier). Flour particle-size distribution was determined by sifting $20 \mathrm{~g}$ of flour through US no. 40 (420 $\mu \mathrm{m}$ openings), US no. 60 (250 $\mu \mathrm{m}$ openings), and US no. $100(149 \mu \mathrm{m}$ openings $)$ sieves for $160 \mathrm{~s}$ on a 
gyratory shaker to separate them into bran and germ (>420 m), coarse $(250-420 \mu \mathrm{m})$, intermediate (149-250 $\mu \mathrm{m})$, and fine $(<149 \mu \mathrm{m})$ flours. Particle-size index was calculated by using PSI $=\sum a_{i} b_{i}$, where a is the weight of material through sieve $i$, and $b=\mathrm{US}$ standard sieve number (Galiba, Rooney, Waniska, \& Miller, 1987). A larger PSI number meant that average particle size was smaller. Water absorption index was measured by the method of AACC 56-10 (1995) using $1 \mathrm{~g}$ of flour. The amount of water held after centrifugation was expressed as percent of flour weight.

\subsection{Rapid visco analyzer measurements}

Flour pasting properties were measured using a Rapid Visco Analyser (Model RVA-4, Newport Scientific, Warriewood, Australia). In the RVA, the short temperature profile (13 min) was used and the mixture was stirred at $960 \mathrm{rpm}$ for $10 \mathrm{~s}$, and then at $160 \mathrm{rpm}$ for the remainder of the test. A mixture of $3.5 \mathrm{~g}$ flour and $25.0 \mathrm{ml}$ water was held at $50{ }^{\circ} \mathrm{C}$ for $1 \mathrm{~min}$ and subsequently heated to $95^{\circ} \mathrm{C}$ at $12.2^{\circ} \mathrm{C} / \mathrm{min}$. Holding time at $95^{\circ} \mathrm{C}$ was $2.5 \mathrm{~min}$. Subsequently, the sample was cooled to $50{ }^{\circ} \mathrm{C}$ at $12.2^{\circ} \mathrm{C} /$ min, where it was kept for $2.1 \mathrm{~min}$. The RVA parameters measured were peak viscosity (the maximum hot paste viscosity), holding strength (the trough at the minimum hot paste viscosity), and final viscosity (the viscosity at the end of the test after cooling to 50C and holding at this temperature). Breakdown (peak viscosity minus holding strength) and setback (final viscosity minus holding strength) were calculated from these values. All values were expressed in Rapid Visco Analyser units (RVU).

\subsection{Cooking quality of decorticated grain}

The texture (hardness, adhesiveness, and cohesiveness) of the cooked sorghum was determined by texture profile analysis (TPA) test using a TA-XT2 texture analyzer (Texture Technologies Corp., Scarsdale, NY) as described by Champagne et al. (1998) with minor modifications. A 10-g sample of decorticated sorghum was combined with $100 \mathrm{ml}$ water in a 150-ml beaker and cooked for $10 \mathrm{~min}$ in a National Pressure Cooker (Model SR-106N, Matsushita Electric Industrial Co., Ltd., Japan). The outer portion of the cooker contained $500 \mathrm{ml}$ of water. When the cooking cycle was complete, the cooker automatically shifted to a "warm" setting. The cooked sorghum was held an additional $10 \mathrm{~min}$.

After cooking, the excess water was drained from the grain using a US No. 10 screen for $10 \mathrm{~min}$. The drained cooked grain samples were weighed, placed in a beaker, covered with parafilm, and allowed to cool for $1 \mathrm{~h}$. The cooked sorghum was arranged in a single grain layer on the base plate, a compression plate was set at $5 \mathrm{~mm}$ above the base, and a two-cycle compression program (force vs. distance) was used to allow the plate to travel
$4.9 \mathrm{~mm}$, return, and repeat. Test speed was $1 \mathrm{~mm} / \mathrm{s}$. A 38-mm diameter cylinder plunger was employed. The test was repeated on three replicate samples. Parameters derived from the two-cycle curves of the TPA test were: hardness, adhesiveness and cohesiveness, as described by Bourne (1982).

Alkali stiffness measurements were performed using a modified method described by Cagampang, Perez, and Juliano (1973). The modified method consisted of placing a culture tube with $200 \mathrm{mg}$ of flour and $3 \mathrm{ml}$ of $0.2 \mathrm{~N}$ potassium hydroxide $(\mathrm{KOH})$ in a vigorously boiling water bath for $8 \mathrm{~min}$, and allowing the thickened mixture to stand upright at room temperature. Gel consistency was then read as per Cagampang et al. (1973) by laying the tubes horizontally and measuring the length of the gel after $30 \mathrm{~min}$.

\subsection{Statistical analysis}

With the exception of color and cooking quality properties, the experimental design for assessment of physiochemical properties, milling properties, and RVA properties was split plot with seedlots considered whole plots, kernel size subplots, and the experiment replicated two times. Analysis of variance was conducted using the SAS (1990) model: dependent variable $=$ rep seedlot rep $\times$ seedlot kernelsize kernelsize $\times$ seedlot. LSDs were calculated for kernel size class means.

Due to the large amount of sample required for cooking quality tests, replication of cooking quality tests was not possible. Color tests were also not replicated. Cooking and color quality data were therefore analyzed as a randomized complete block with seedlots considered replications using the SAS model dependent variable $=$ rep kernelsize. LSDs were calculated for kernel size class means. Data from red and white seedlots was also analyzed separately for color parameters since pericarp color would be expected to impact flour and color of ground whole grain samples.

\section{Results and discussion}

\subsection{Physical and chemical properties of grain sorghum}

Kernel size effects were significant for hardness, protein, and ash (Table 1). Kernel size did not affect starch content. Large and medium size sorghum kernels from these six seedlots were harder than small kernels (Table 2). Small kernels averaged three times greater dry matter removal following 1 min of dehulling than large and medium size kernels. Although the kernel size $\times$ seedlot interaction was significant for hardness, ranking of kernel size classes for hardness was consistent within all seedlots, with small kernel size always exhibiting higher percent dry matter loss following 1 
minute of decortication. The association of small kernel size with reduced hardness in this study was unexpected and disagrees with results reported by Wills and Ali (1983). These are also contrary to cursory observations of hardness (resistance to crushing) and kernel size we have made in unrelated experiments and may be due too differences in methodologies.

Protein content of the large kernel size averaged slightly higher than medium and small kernel classes. The kernel size $\times$ seedlot interaction was significant for protein content. Within five of the seedlots, the large kernel class exhibited highest protein content. Ash content was slightly higher in the small kernel class. The kernel size $\times$ seedlot interaction was again significant, but the small kernel class exhibited significantly higher ash content than either medium or large kernel classes in all seedlots.

Kernel size effects were significant for color of ground whole grain (Table 3). Relative whiteness $\left(L^{*}\right)$ was higher for large kernels in both red and white seedlots. Red-green chromaticity $\left(a^{*}\right)$ and yellow-blue $\left(b^{*}\right)$ chromaticity was slightly higher for large kernels from red seedlots. In white seedlots, $a^{*}$ and $b^{*}$ was slightly higher for small kernels.

These results indicate that large kernel size was associated with higher physical and chemical quality in these sorghum seedlots. Large kernels were harder (smaller relative loss of mass following $1 \mathrm{~min}$ of decortication), had higher protein concentration, lower ash content, and were brighter than small kernels.

\subsection{Dry milling and flour characteristics}

Kernel size had significant effects on sorghum flour. Although kernel size $\times$ seedlot interactions were sig-

Table 1

Significance ( $F$-test) for grain sorghum quality variables

\begin{tabular}{|c|c|c|c|}
\hline Variable & Seedlot effect & Kernel size & $\begin{array}{l}\text { Kernel } \\
\text { size } \times \text { seedlot }\end{array}$ \\
\hline \multicolumn{4}{|l|}{ Whole grain } \\
\hline Hardness & 0.0002 & 0.0001 & 0.0001 \\
\hline Starch & 0.0208 & 0.0857 & 0.3993 \\
\hline Protein & 0.0001 & 0.0001 & 0.0001 \\
\hline Ash & 0.0001 & 0.0001 & 0.0001 \\
\hline \multicolumn{4}{|l|}{ Flour } \\
\hline Fine particles & 0.0001 & 0.0001 & 0.0042 \\
\hline Medium particles & 0.0005 & 0.0001 & 0.4211 \\
\hline Large particles & 0.0023 & 0.0001 & 0.0391 \\
\hline Particle size index & 0.0012 & 0.0001 & 0.0065 \\
\hline Mill yield & 0.0191 & 0.0012 & 0.8021 \\
\hline Water absorption & 0.0005 & 0.0001 & 0.0009 \\
\hline \multicolumn{4}{|l|}{ Rapid visco analyzer } \\
\hline Peak viscosity & 0.0001 & 0.0008 & 0.0004 \\
\hline Hold viscosity & 0.0025 & 0.0060 & 0.0001 \\
\hline Break viscosity & 0.0001 & 0.0004 & 0.0001 \\
\hline Final viscosity & 0.0001 & 0.0003 & 0.0001 \\
\hline Setback viscosity & 0.0001 & 0.0001 & 0.0001 \\
\hline
\end{tabular}

nificant for percent fine and percent large particles (Table 1), flour from small kernels always had a higher percentage of fine particles than flour from medium or large kernels (Table 4). In half of the seedlots, flour from large kernels had a higher percentage of large particles than flour from small kernels. As would be expected, where significant differences were shown in

Table 2

Physical and chemical properties of whole grain sorghum

\begin{tabular}{|c|c|c|c|c|c|}
\hline & \multirow[t]{2}{*}{ Seedlot $^{\mathrm{a}}$} & \multicolumn{4}{|c|}{ Kernel size } \\
\hline & & Large & Medium & Small & $\begin{array}{l}\text { LSD } \\
(P \leqslant 0.05)\end{array}$ \\
\hline \multirow{7}{*}{$\begin{array}{l}\text { Hardness }(\% \mathrm{DM} \text { loss } \\
\text { following } 1 \mathrm{~min} \\
\text { decortication }\end{array}$} & 1 & 7.15 & 7.85 & 15.95 & 0.70 \\
\hline & 2 & 4.00 & 3.95 & 19.50 & 1.68 \\
\hline & 3 & 7.75 & 9.00 & 15.05 & 2.13 \\
\hline & 4 & 4.40 & 6.65 & 30.10 & 4.3 \\
\hline & 5 & 5.75 & 6.90 & 18.40 & 2.7 \\
\hline & 6 & 4.20 & 4.40 & 11.75 & 1.4 \\
\hline & Mean & 5.5 & 6.5 & 18.5 & 0.5 \\
\hline \multirow[t]{7}{*}{ Starch $(\%)$} & 1 & 78.6 & 77.4 & 76.6 & 0.8 \\
\hline & 2 & 74.1 & 72.3 & 71.5 & $\mathrm{NS}^{\mathrm{b}}$ \\
\hline & 3 & 77.1 & 78.0 & 77.5 & NS \\
\hline & 4 & 76.1 & 75.0 & 73.0 & NS \\
\hline & 5 & 75.5 & 73.5 & 75.4 & NS \\
\hline & 6 & 72.7 & 72.3 & 72.9 & NS \\
\hline & Mean & 75.7 & 74.7 & 74.5 & NS \\
\hline \multirow[t]{7}{*}{ Protein $(\%)$} & 1 & 12.24 & 11.36 & 11.24 & 0.31 \\
\hline & 2 & 12.42 & 11.70 & 12.34 & 0.03 \\
\hline & 3 & 12.15 & 11.38 & 10.97 & 0.08 \\
\hline & 4 & 11.71 & 12.34 & 13.03 & 0.23 \\
\hline & 5 & 12.56 & 11.72 & 11.95 & 0.05 \\
\hline & 6 & 15.21 & 14.54 & 15.00 & 0.06 \\
\hline & Mean & 12.72 & 12.16 & 12.42 & 0.03 \\
\hline \multirow[t]{7}{*}{ Ash (\%) } & 1 & 1.55 & 1.51 & 1.66 & 0.03 \\
\hline & 2 & 1.73 & 1.71 & 1.92 & 0.06 \\
\hline & 3 & 1.45 & 1.43 & 1.54 & 0.02 \\
\hline & 4 & 1.60 & 1.80 & 2.08 & 0.09 \\
\hline & 5 & 1.37 & 1.45 & 1.67 & 0.05 \\
\hline & 6 & 1.56 & 1.66 & 1.79 & 0.06 \\
\hline & Mean & 1.56 & 1.60 & 1.78 & 0.01 \\
\hline
\end{tabular}

a Seedlot $1=7 \mathrm{R} 37 \mathrm{E}, 2=\mathrm{S}_{7}$ from $35 \times \mathrm{PI}, 3=\mathrm{A} 425,4=\mathrm{BT} \times 623$, $5=\mathrm{GR} 55 \mathrm{E}, 6=\mathrm{S}_{8}$ from low HCN-p RP2B population.

Table 3

Color of ground whole grain sorghum graded by kernel size

\begin{tabular}{rrrrl}
\hline \multicolumn{5}{c}{ Kernel size } \\
\cline { 2 - 5 } & Large & Medium & Small & $\begin{array}{l}\text { LSD } \\
(P \leqslant 0.05)\end{array}$ \\
\hline Red kernels only_color $L^{*}$ & 58.62 & 58.21 & 57.09 & 0.35 \\
$a^{*}$ & 4.11 & 3.94 & 3.59 & 0.18 \\
$b^{*}$ & 8.33 & 8.11 & 7.91 & 0.09 \\
White kernels only_color $L^{*}$ & 65.18 & 66.40 & 63.17 & 0.29 \\
$a^{*}$ & 0.89 & 1.25 & 1.63 & 0.17 \\
$b^{*}$ & 8.61 & 8.60 & 8.79 & 0.15 \\
Combined kernels color $L^{*}$ & 61.90 & 61.30 & 60.13 & 0.23 \\
$a^{*}$ & 2.50 & 2.59 & 2.61 & 0.20 \\
$b^{*}$ & 8.74 & 8.35 & 8.34 & 0.11 \\
\hline
\end{tabular}


individual seedlots, particle size index was highest for flour from small kernels.

Milling yield was highest for large kernels with large kernels averaging $66.8 \%$ yield and small kernels averaging $64.4 \%$ yield, and the size $\times$ seedlot interaction was not significant. Water absorption index was highest for large kernels. Although the kernel size $\times$ seedlot interaction was significant for water absorption index, ranking of kernel size classes for water absorption index was consistent with large kernel size always exhibiting

Table 4

Milling and flour properties grain sorghum graded by kernel size

\begin{tabular}{|c|c|c|c|c|c|}
\hline & \multirow[t]{2}{*}{ Seedlot $^{\mathrm{a}}$} & \multicolumn{4}{|c|}{ Kernel size } \\
\hline & & Large & Medium & Small & $\begin{array}{l}\text { LSD } \\
(P \leqslant 0.05)\end{array}$ \\
\hline \multirow[t]{7}{*}{ Fine particles $(\%)$} & 1 & 29.1 & 29.0 & 34.2 & $\mathrm{NS}^{\mathrm{b}}$ \\
\hline & 2 & 24.4 & 25.4 & 29.6 & 3.9 \\
\hline & 3 & 27.9 & 27.7 & 35.3 & 2.6 \\
\hline & 4 & 23.0 & 26.6 & 33.1 & 4.0 \\
\hline & 5 & 27.9 & 28.4 & 33.7 & 2.6 \\
\hline & 6 & 22.8 & 22.1 & 25.2 & 1.7 \\
\hline & Mean & 25.8 & 26.5 & 31.8 & 0.8 \\
\hline \multirow[t]{7}{*}{ Medium particles $(\%)$} & 1 & 37.1 & 38.3 & 35.8 & NS \\
\hline & 2 & 43.0 & 43.0 & 40.1 & NS \\
\hline & 3 & 38.8 & 39.4 & 36.1 & NS \\
\hline & 4 & 40.1 & 41.2 & 36.7 & 2.1 \\
\hline & 5 & 38.1 & 36.2 & 34.1 & NS \\
\hline & 6 & 39.8 & 40.2 & 38.5 & NS \\
\hline & Mean & 39.5 & 39.7 & 36.9 & 0.9 \\
\hline \multirow[t]{7}{*}{ Large particles (\%) } & 1 & 29.0 & 26.0 & 21.5 & NS \\
\hline & 2 & 31.0 & 27.7 & 23.2 & 5.6 \\
\hline & 3 & 28.5 & 25.3 & 21.3 & NS \\
\hline & 4 & 33.1 & 28.0 & 21.0 & 4.5 \\
\hline & 5 & 29.2 & 27.0 & 21.9 & 1.1 \\
\hline & 6 & 31.7 & 31.9 & 29.4 & NS \\
\hline & Mean & 27.6 & 27.6 & 23.0 & 1.2 \\
\hline \multirow[t]{7}{*}{ Particle size index } & 1 & 63.0 & 62.2 & 64.2 & NS \\
\hline & 2 & 62.6 & 62.2 & 63.0 & NS \\
\hline & 3 & 62.6 & 61.5 & 65.3 & 1.2 \\
\hline & 4 & 60.2 & 62.5 & 63.5 & 1.2 \\
\hline & 5 & 62.4 & 60.9 & 62.9 & 0.05 \\
\hline & 6 & 59.3 & 59.0 & 60.0 & NS \\
\hline & Mean & 61.7 & 61.4 & 63.1 & 0.5 \\
\hline \multirow[t]{7}{*}{ Milling yield (\%) } & 1 & 66.6 & 65.0 & 64.0 & 1.9 \\
\hline & 2 & 67.8 & 67.2 & 65.0 & 1.9 \\
\hline & 3 & 66.7 & 64.7 & 64.7 & NS \\
\hline & 4 & 67.3 & 65.6 & 65.1 & NS \\
\hline & 5 & 66.6 & 64.2 & 62.8 & 1.2 \\
\hline & 6 & 65.9 & 65.9 & 65.1 & NS \\
\hline & Mean & 66.8 & 65.4 & 64.4 & 1.0 \\
\hline \multirow[t]{7}{*}{ Water absorption index } & 1 & 159.6 & 154.2 & 147.1 & 5.6 \\
\hline & 2 & 163.2 & 163.0 & 160.8 & NS \\
\hline & 3 & 162.0 & 154.1 & 147.0 & 9.0 \\
\hline & 4 & 167.5 & 164.3 & 152.5 & 5.1 \\
\hline & 5 & 160.8 & 152.8 & 148.0 & 4.4 \\
\hline & 6 & 164.1 & 171.8 & 161.3 & NS \\
\hline & Mean & 162.9 & 160.0 & 152.8 & 1.7 \\
\hline
\end{tabular}

a Seedlot $1=7 \mathrm{R} 37 \mathrm{E}, 2=\mathrm{S}_{7}$ from $35 \times \mathrm{PI}, 3=\mathrm{A} 425,4=\mathrm{BT} \times 623$,

$5=\mathrm{GR} 55 \mathrm{E}, 6=\mathrm{S}_{8}$ from low HCN-p RP2B population.

b NS, Not significant. highest water absorbance index, with the exception of one seedlot in which differences were not detected.

As in ground whole grain, kernel size effects were significant for color of sorghum flour (Table 5). Relative whiteness $\left(L^{*}\right)$ was higher for flour from large kernels in both red and white seedlots, and $a^{*}$ and $b^{*}$ was highest in flour made from small kernels. However in red seed, kernel size effects on $a^{*}$ and $b^{*}$ were reversed in flour compared with ground whole grain with highest $a^{*}$ and $b^{*}$ associated with flour made from small kernels.

Conflicting conclusions on the effect of kernel size on dry milling characteristics of grain sorghum are found in the literature. Wills and Ali (1982) reported that decorticated grain recovery was higher for small grain when Australian sorghum cultivars were decorticated with a pearler. Kirleis and Cosby (1982) reported US sorghum grain with large kernel size having better pearling properties than grain with small kernels given the same endosperm hardness. Within the set of six US grown grain sorghum seedlots used in this study, large kernel size contributed to higher milling yields. Flour from large kernels had higher water absorbance, brighter white color, and larger particle size.

\subsection{Rapid visco analyzer measurements}

A summary of the RVA pasting properties of flours from large, medium, and small kernel size classes of the six seedlots are shown (Table 6). Kernel size $\times$ seedlot interactions were significant for RVA pasting properties (Table 1), and appear to be due to differential ranking of kernel size classes for the RVA parameters. For example, hold viscosity is highest in flour made from large kernels in seedlot 4 and highest in flour made from small kernel in seedlot 5. Pasting properties of sorghum flour are a key to understanding the physical characteristics and potential utilization. Aboubacar and Hamaker (1999), and Akingbala and Rooney (1987) reported differences among sorghum cultivars and an apparent association of amylose con-

Table 5

Flour color of grain sorghum graded by kernel size

\begin{tabular}{|c|c|c|c|c|}
\hline & \multicolumn{4}{|c|}{ Kernel Size } \\
\hline & Large & Medium & Small & $\begin{array}{l}\text { LSD } \\
(P \leqslant 0.05)\end{array}$ \\
\hline Red kernels only-color $L^{*}$ & 66.88 & 66.15 & 64.35 & 0.36 \\
\hline$a^{*}$ & 0.79 & 1.31 & 1.84 & 0.18 \\
\hline$b^{*}$ & 7.80 & 7.73 & 7.47 & 0.15 \\
\hline White kernels only - color $L^{*}$ & 68.98 & 68.46 & 66.38 & 0.48 \\
\hline$a^{*}$ & -0.60 & -0.17 & 1.08 & 0.47 \\
\hline$b^{*}$ & 7.58 & 8.07 & 8.49 & 0.13 \\
\hline Combined kernels - color $L^{*}$ & 67.93 & 67.30 & 65.36 & 0.26 \\
\hline$a^{*}$ & 0.09 & 0.57 & 1.46 & 0.26 \\
\hline$b^{*}$ & 7.69 & 7.90 & 7.98 & 0.18 \\
\hline
\end{tabular}


Table 6

Rapid visco analyzer properties of grain sorghum graded by kernel size

\begin{tabular}{|c|c|c|c|c|c|}
\hline & \multirow[t]{2}{*}{ Seedlot ${ }^{\mathrm{a}}$} & \multicolumn{4}{|c|}{ Kernel } \\
\hline & & Large & Medium & Small & $\begin{array}{l}\text { LSD } \\
(P \leqslant 0.05)\end{array}$ \\
\hline \multirow[t]{7}{*}{ Peak viscosity $(\mathrm{RVU})^{\mathrm{b}}$} & 1 & 238.6 & 245.1 & 233.4 & $\mathrm{NS}^{\mathrm{c}}$ \\
\hline & 2 & 194.2 & 186.8 & 173.4 & NS \\
\hline & 3 & 213.4 & 225.5 & 221.2 & NS \\
\hline & 4 & 205.5 & 185.3 & 197.3 & 11.4 \\
\hline & 5 & 211.3 & 222.6 & 215.5 & NS \\
\hline & 6 & 183.8 & 163.3 & 145.8 & 12.3 \\
\hline & Mean & 207.8 & 204.8 & 197.8 & 4.3 \\
\hline \multirow[t]{7}{*}{ Hold viscosity (RVU) } & 1 & 151.0 & 153.0 & 154.3 & NS \\
\hline & 2 & 146.9 & 139.8 & 132.6 & 10.4 \\
\hline & 3 & 138.8 & 137.5 & 126.0 & NS \\
\hline & 4 & 138.4 & 126.2 & 139.3 & 6.5 \\
\hline & 5 & 141.1 & 149.2 & 156.3 & 10.5 \\
\hline & 6 & 136.6 & 127.9 & 119.0 & 4.7 \\
\hline & Mean & 142.1 & 138.9 & 137.9 & 2.4 \\
\hline \multirow[t]{7}{*}{ Break viscosity (RVU) } & 1 & 87.9 & 92.1 & 79.1 & NS \\
\hline & 2 & 47.3 & 47.0 & 40.8 & NS \\
\hline & 3 & 74.6 & 88.0 & 95.2 & 12.4 \\
\hline & 4 & 67.2 & 59.1 & 57.9 & 5.4 \\
\hline & 5 & 70.2 & 73.4 & 59.2 & 9.3 \\
\hline & 6 & 47.7 & 35.4 & 26.5 & 6.7 \\
\hline & Mean & 65.8 & 65.8 & 59.8 & 2.7 \\
\hline \multirow[t]{7}{*}{ Final viscosity (RVU) } & 1 & 294.4 & 297.5 & 304.9 & 1.1 \\
\hline & 2 & 312.1 & 303.8 & 309.3 & NS \\
\hline & 3 & 276.1 & 271.6 & 253.5 & NS \\
\hline & 4 & 283.2 & 270.4 & 327.2 & 19.5 \\
\hline & 5 & 287.9 & 295.8 & 299.7 & NS \\
\hline & 6 & 284.6 & 273.2 & 274.3 & 6.6 \\
\hline & Mean & 289.7 & 285.4 & 294.8 & 3.5 \\
\hline \multirow[t]{7}{*}{ Setback viscosity (RVU) } & 1 & 143.4 & 144.5 & 150.6 & NS \\
\hline & 2 & 165.3 & 164.0 & 176.7 & 4.2 \\
\hline & 3 & 137.4 & 134.1 & 127.5 & NS \\
\hline & 4 & 144.8 & 144.3 & 187.8 & 14.9 \\
\hline & 5 & 146.8 & 146.5 & 143.4 & NS \\
\hline & 6 & 148.0 & 145.3 & 155.0 & 1.8 \\
\hline & Mean & 147.6 & 146.4 & 156.8 & 2.2 \\
\hline
\end{tabular}

a Seedlot $1=7 \mathrm{R} 37 \mathrm{E}, 2=\mathrm{S}_{7}$ from $35 \times \mathrm{PI}, 3=\mathrm{A} 425,4=\mathrm{BT} \times 623$, $5=\mathrm{GR} 55 \mathrm{E}, 6=\mathrm{S}_{8}$ from low HCN-p RP2B population.

b RVU, rapid visco analyzer units.

c NS, Not significant.

tent with peak viscosity using a Brabender Visco-Amylograph. Our results confirmed differences due to seedlot (Table 1), but because of significant kernel size $\times$ seedlot interactions, gave no consistent evidence that particular RVA pasting properties can be attributed to kernel size.

\subsection{Cooking quality of decorticated grain}

Using TPA, cooked decorticated grain from large kernels was harder, less sticky, and more cohesive than from small kernels (Table 7). Cooked weight was higher for samples from the small size class, indicating greater water absorption. Cagampang, Kirleis, and Marks
Table 7

Cooking quality of grain sorghum graded by kernel size

\begin{tabular}{|c|c|c|c|c|}
\hline & \multicolumn{4}{|c|}{ Kernel size } \\
\hline & Large & Medium & Small & $\begin{array}{l}\text { LSD } \\
(P \leqslant 0.05)\end{array}$ \\
\hline $\begin{array}{l}\text { Cooked weight (g) } \\
\text { Cooked texture }\end{array}$ & 24.6 & 26.5 & 29.2 & 1.8 \\
\hline Hardness (kg) & 12.8 & 11.5 & 10.3 & 1.0 \\
\hline Adhesiveness (TPU) & -14.6 & -38.9 & -40.1 & 16.0 \\
\hline $\begin{array}{l}\text { Cohesiveness (TPU) } \\
\text { Alkali stiffness }\end{array}$ & 0.365 & 0.349 & 0.340 & 0.014 \\
\hline Gel consistency (mm) & 63.6 & 65.8 & 36.3 & 8.8 \\
\hline
\end{tabular}

a TPU, textural properties analyzer units.

(1984) reported that soft sorghum grain absorbed more water during cooking that hard grain. Although we did not directly test the effect of hardness on water absorption, our results support that conclusion since small kernels were shown to be softer than large kernels in all seedlots (Table 2).

Alkali stiffness values for large and medium sized grain (gel consistency $=64$ and $66 \mathrm{~mm}$, respectively) were nearly double the value of small sized grain (gel consistency $=37 \mathrm{~mm}$ ) (Table 7). Murty, Patil, and House (1982) reported a gel flow range of 49-115 mm for 25 cultivars using dehulled sorghum grain, and a positive association with the texture of several traditional sorghum preparations. The alkali stiffness values for large and medium kernels used in this study fall within that range, but values for small kernels fall below the range reported by Murty et al. (1982) suggesting a negative association of small kernel size with texture of some sorghum preparations.

\section{Conclusion}

After accounting for variation due to seedlot and the interaction of kernel size and seedlot, kernel size effects were significant for most grain quality parameters measured. Large kernel size was associated with higher physical and chemical quality parameters. Large kernels were harder (lost less relative mass during $1 \mathrm{~min}$ of decortication), higher in protein concentration, and lower ash. Milling yields were higher from large kernels, and flour from large kernels had higher water absorbance, brighter white color, and larger particle size. Kernel size effects on RVA properties were not consistent.

\section{References}

Aboubacar, A., \& Hamaker, B. R. (1999). Physicochemical properties of flours that relate to sorghum couscous quality. Cereal Chemistry, $76,308-313$. 
Akingbala, J. O., \& Rooney, L. W. (1987). Paste properties of sorghum flour and starches. Journal of Food Processing and Preservation, 11, 13-24.

American Association of Cereal Chemists. (1995). Approved methods of the AACC (9th ed). Method 08-01, revised October 1981; Method 44-15A, revised October 1994; Method 46-18, revised October 1994; Method 56-10, approved October 1997; Method 76-13, approved November 1995. The Association: St. Paul, MN.

Bourne, M. C. (1982). Principles of objective texture measurement. In M. C. Bourne (Ed.), Food texture and viscosity: concept and measurement (pp. 44-117). New York: Academic Press.

Cagampang, G. B., Griffith, J. E., \& Kirleis, A. W. (1982). Modified adhesion test for measuring stickiness of sorghum porridges. Cereal Chemistry, 59, 234-235.

Cagampang, G. B., Kirleis, A. W., \& Marks, J. S. (1984). Application of small sample back extrusion test for measuring texture of cooked sorghum grain. Journal of Food Science, 49, 278-280.

Cagampang, G. B., Perez, C. M., \& Juliano, B. O. (1973). A gel consistency test for eating quality of rice. Journal of the Science of Food and Agriculture, 24, 1589-1594.

Champagne, E. T., Lyon, B. G., Min, B. K., Vinyard, B. T., Bett, K. L., Barton, F. E., Webb, B. D., McClung, A. M., Moldenhauer, K. A., Linscombe, S., McKenzie, K. S., \& Kohlwey, D. E. (1998). Effects of postharvest processing on texture profile analysis of cooked rice. Cereal Chemistry, 75, 181-186.

FAO. (1995). Introduction. In: Sorghum and millets in human nutrition, (pp. 1-12). Food and Agriculture Organization of the United Nations, Rome, Italy.

Farias, G. A. Y. (1986). Proso millet: milling characteristics, flour functionality and starch properties. MS dissertation, University of Nebraska, Lincoln, NE.

Galiba, M. H., Rooney, L. W., Waniska, R. D., \& Miller, F. R. (1987). The preparation of sorghum and millet couscous in West Africa. Cereal Foods World, 32, 878-884.

Heiniger, R. W., Vanderlip, R. L., \& Kofoid, K. D. (1993). Caryopsis weight patterns within the sorghum panicle. Crop Science, 33, 543-549.
ICRISAT. (1999). The world sorghum and millet economies; facts, trends and outlook. Patancheru, India: ICRISAT (International Crops Research Institute for the Semi-Arid Tropics).

Kirleis, A. W., \& Cosby, K. D. (1982). Sorghum hardness: comparison of methods for its evaluation. In L. W. Rooney, \& D. S. Murty (Eds.), Proceedings of the International Symposium on Sorghum Grain Quality (pp. 231-241). Patancheru, India: ICRISAT.

Murty, D. S., Patil, H. D., \& House, L. R. (1982). Cultivar difference for gel consistency in sorghum. In L. W. Rooney, \& D. S. Murty (Eds.), Proceedings of the International Symposium on Sorghum Grain Quality (pp. 289-392). Patancheru, India: ICRISAT.

Oomah, B. D., Reichert, R. D., \& Youngs, C. G. (1981). A novel, multisample, tangential abrasive dehulling device (TADD). Cereal Chemistry, 58, 92-395.

Perten, H. (1976). Specific characteristics of millet and sorghum milling. In: D. A. V. Dendy (ed.), Proceedings of the Symposium on Sorghum and Millets for Human Food. (pp. 47-51). London: Tropical Products Institute.

Rooney, L. W., Kirleis, A. W., \& Murty, D. S. (1986). Traditional foods from sorghum: their production evaluation and nutritional value. In Y. Pomeranz (Ed.), Advances in cereal science and technology. Vol. 8 (pp. 317-353). St. Paul, MN: American Association Cereal Chemistry.

Rooney, L. W., \& Sullins, R. D. (1970). Chemical, physical and morphological properties of diploid and tetraploid Sorghum bicolor (L.) Moench kernels. Crop Science, 10, 97-99.

SAS. (1970). User's guide. (6th ed.). Cary, NC: The Institute.

Sosland, L. J. (1998). Grain sorghum: the other white grain. World Grain, September, 6-10.

Suhendro, E. L., McDonough, C. M., Rooney, L. W., Waniska, R. D., \& Yetneberk, S. (1998). Effects of processing conditions and sorghum cultivar on alkaline-processed snacks. Cereal Chemistry, 75, 187-193.

Wills, R. B. H., \& Ali, M. R. (1983). Effect of grain size on dehulling of sorghum. Cereal Chemistry, 60, 12-14. 